\title{
Shifting the Burden of Production under Rule 4(k)(2): A Cost-Minimizing Approach
}

\author{
Julius Ness Richardson $\dagger$
}

A court must have personal jurisdiction over a defendant in order to pass judgment on the underlying merits of a claim. '. Personal jurisdiction requires both compliance with due process and a statutory basis: ${ }^{2}$ constitutional due process requires that the defendants have minimum contacts with the forum; the statutory basis requires that a statute authorize the exercise of jurisdiction and may be satisfied by state statutes of general application in federal courts. ${ }^{4}$ If federal plaintiffs borrow from state statutes, the federal court must determine whether the defendant has the requisite minimum contacts with the state to exercise personal jurisdiction. ${ }^{5}$ Federal Rule of Civil Procedure 4(k)(1) encapsulates this traditional standard. ${ }^{6}$

When a defendant does not have minimum contacts with any single forum state to comport with due process under traditional Rule $4(\mathrm{k})(1){ }^{7}$ Rule $4(\mathrm{k})(2)^{8}$ may provide a means of exercising personal jurisdiction to enforce a federal claim. If such a defendant has sufficient contacts nationwide to comport with due process, then a federal court may subject the defendant to its jurisdiction under Rule $4(\mathrm{k})(2) .{ }^{9}$ In

\section{$\dagger$ B.S. 1999, Vanderbilt University; J.D. Candidate 2003, The University of Chicago.}

1 Charles Alan Wright and Arthur R. Miller, 4 Federal Practice and Procedure: Civil $3 d$ $\S 1064$ at 334 (West 3d ed 1987) (noting the preliminary inquiry is "whether the court has the power to summon a defendant before it to adjudicate a claim against him").

2 Id (stating that personal jurisdiction is "governed primarily by the Supreme Court's interpretations of the Due Process Clause of the Constitution and a network of state and federal statutory provisions dealing with a defendant's amenability to suit").

3 See International Shoe Co $v$ Washington, 326 US 310, 316-20 (1945) (finding that the Due Process Clause bars a state from binding a defendant who lacks contacts or relations with that state to an in personam judgment).

4 Wright and Miller, 4 Federal Practice and Procedure $\$ 1064$ at 334 (cited in note 1).

5 Id $\S 1068.1$ at 616 (discussing the exercise of jurisdiction by a federal court over a defendant who is not within the reach of any state's statute).

6 FRCP 4(k)(1) ("Service of a summons or filing a waiver of service is effective to establish jurisdiction over the person of a defendant (A) who could be subjected to the jurisdiction of a court of general jurisdiction in the state in which the district court is located.") (emphasis added).

7 Id.

8 FRCP 4(k)(2). See Part I.D for the text and judicial interpretation of Rule 4(k)(2).

9 Rule 4(k)(2) might apply in the following situation adopted from Omni Capital International, Ltd $v$ Rudolf Wolff \& Co, Ltd, 484 US 97 (1987): A British corporation violates a federal law giving rise to a private federal claim. The British corporation interacts with the United States extensively, but its contacts are sufficiently spread among the several states so as to not be subject to personal jurisdiction under traditional federal borrowing of state personal jurisdictional 
order to satisfy Rule $4(\mathrm{k})(2)$, the court must also determine that the defendant "is not subject to the jurisdiction of the courts of general jurisdiction of any state."

In order to determine whether the defendant may be subjected to the jurisdiction of the court under Rule $4(\mathrm{k})(2)$, the court must assign to a party the burden of proof. This burden of proof includes the burden of pleading the jurisdictional elements, the burden of producing evidence on the elements, and the burden of persuading the court that it is correct." Given that Rule 4(k)(2) encompasses both affirmative elements (demonstrating consistency with the Constitution and laws) and negative elements (demonstrating that the defendant is not subject to the jurisdiction of a state court), the assignment of the burden may determine the outcome of many cases.

Part I of this Comment provides a background of personal jurisdiction and Rule 4(k)(2). Part II discusses how courts currently allocate the burden of production under Rule 4(k)(2). This Part looks first at the traditional allocation of the burden to the plaintiff, then at a complete shift of the burden to the defendant, and finally at a burdenshifting ${ }^{12}$ approach. Part III answers the normative question of how the burden should be allocated. First, Part III.A explains the basic economic framework in which burden allocation decisions should be made and then applies that framework to Rule 4(k)(2). Part III.B then reveals that unitary allocation to the plaintiff and unitary allocation to the defendant are both second-best options with significant drawbacks. Part IV concludes that the burden-shifting approach best reduces costs by screening out meritless cases and allocating the majority of the burden of production to the lowest cost provider.

\section{PeRsonal JuRisdiction AND RULE 4(K)(2)}

\section{A. History of Personal Jurisdiction}

The Judiciary Act of 1789 initially limited the personal jurisdiction of federal trial courts to entities upon which process was served within the court's district, which was defined by the borders of the

requirements. Rule $4(\mathrm{k})(2)$ provides a court with the statutory authority to treat the nation as the effective forum. The court may aggregate the British corporation's national contacts to meet the Fifth Amendment's due process requirements, subjecting the British corporation to federal jurisdiction.

10 FRCP 4(k)(2).

11 John W. Strong, ed, McCormick on Evidence $\$ 337$ (West 5th ed 1999) (discussing burdens of proof). See notes 26-30 and accompanying text (discussing the three burdens of proof).

12 For example, a plaintiff must first meet some burden before the remainder of the burden shifts to the defendant. See United States v Swiss American Bank, Ltd, 191 F3d 30, 41-42 (1st Cir 1999) (applying a burden-shifting approach for Rule 4(k)(2)). 
state. ${ }^{13}$ Even as Congress established multiple districts in a single state, service within district boundaries largely determined federal courts' jurisdiction. ${ }^{14}$ In 1938, Congress adopted the Federal Rules of Civil Procedure, and Rule 4(f) extended service of process beyond the district to the state in which the federal court was located. ${ }^{15}$ Rule 4 was revised in 1963, shifting the focus to the defendant's actions within the particular state. ${ }^{16}$ As a result of these revisions, federal courts' personal jurisdiction became largely dependent on whether a state court could exercise personal jurisdiction over the defendant.

\section{B. Application of Traditional Personal Jurisdiction}

Federal jurisdiction under Rule $4(\mathrm{k})(1)$ requires both statutory authority independent of the Federal Rules of Civil Procedure and compliance with constitutional due process. ${ }^{17}$ Statutory authority under Rule 4(k)(1) comes in two forms: federal statutes may provide for service of process; ${ }^{18}$ or federal courts may borrow from state statutes of general application ${ }^{19}$ under Rule 4(k)(1)(A).

Constitutional due process requires that the defendant have minimum contacts with the forum. Where statutory authority is bor-

13 Judiciary Act of 1789 , ch $20, \S 11,1$ Stat 73,78 .

14 See FRCP 4, Advisory Committee's Note (1938).

15 See FRCP 4(f) (1938).

16 The shift was accomplished by the following revisions: FRCP 4(e) (1963), allowing service outside the state when a state law would permit it; FRCP 4(i) (1963), allowing international service of process where the federal law or state law provided for it; and FRCP 4(f) (1963), allowing service of process within 100 miles of the courthouse-but not outside the U.S.-for third-party defendants (FRCP 14) and necessary parties (FRCP 19).

17 See, for example, Omni Capital International v Rudolf Wolff \& Co, 484 US 97, 104-08 (1987) (holding that because there was no statutory authority, the due process analysis was unnecessary).

18 See, for example, Clayton Antitrust Act of 1914, 15 USC $\S 22$ (1994) (providing for worldwide service of process for certain corporate antitrust defendants).

19 See, for example, Mass Gen Laws Ch 223A, \& 3 (Law Co-Op 1986) (providing "longarm" jurisdiction).

20 See note 6.

21 International Shoe Co $v$ Washington, 326 US 310, 316-20 (1945) (finding that the Due Process Clause does not contemplate that a state can make a binding in personam judgment against a defendant with no contacts or relations with that state). Due process can be met either under general jurisdiction, which allows any type of action against a defendant, or specific jurisdiction, which only allows actions related to the necessary contacts. General jurisdiction requires the defendant's contacts to be so pervasive that a court in that state may exercise personal jurisdiction over the defendant even where the claims are unrelated to those contacts. See Helicop: teros Nacionales de Colombia, SA v Hall, 466 US 408, 414 n 9 (1984). Specific jurisdiction allows the exercise of jurisdiction only in cases related to the contacts and requires: (1) that the nonresident defendant had "minimum" contacts with the forum state such that there was "fair warning" that the nonresident might be haled into a forum court; (2) that it be reasonable to require the defendant to litigate in the forum state; and (3) that the action arose out of or was related to the defendant's contacts with the forum state. See Central States, Southeast and Southwest Areas Pension Fund v Reimer Express World Corp, 230 F3d 934, 942-43 (7th Cir 2000), cert denied, 532 
rowed from state statutes of general application, the effective forum is that of the state. Thus, the federal court must determine if the defendant has the requisite minimum contacts for a state court constitutionally to exercise personal jurisdiction. ${ }^{23}$ Where the statutory authority is provided by a federal statute, the effective forum is the nation, and the federal court must determine if the defendant has sufficient contacts with the nation as a whole to satisfy due process. ${ }^{24}$ Federal statutes provide this authority only in limited and highly specialized areas such as antitrust. ${ }^{25}$ Thus, under Rule $4(\mathrm{k})(1)$, most defendants must be subject to jurisdiction in the forum state.

The plaintiff traditionally bears the burden of proof on personal jurisdiction. ${ }^{26}$ This burden encompasses the burden of pleading, ${ }^{27}$ the burden of production, ${ }^{28}$ and the burden of persuasion. ${ }^{29}$ In the traditional case, the plaintiff bears all three burdens: (1) the burden of pleading the elements establishing jurisdiction over the defendant; (2) the burden of producing evidence in support of the jurisdictional allegations; and (3) the burden of persuasion in which the plaintiff must convince the judge to exercise jurisdiction over the defendant. ${ }^{30}$

\section{Adoption of Rule 4(k)(2)}

Prior to the addition of Rule $4(\mathrm{k})(2)$, the existence of defendants with sufficient nationwide contacts but with insufficient contacts with

US 943 (2001), citing Burger King Corp v Rudzewicz, 471 US 462, 471-77 (1985).

22 Wright and Miller, 4 Federal Practice and Procedure $\$ 1068.1$ at 616 (cited in note 1).

23 See ISI International, Inc v Borden Ladner Gervais LLP, 256 F3d 548, 552 (7th Cir 2001) (recognizing that Rule $4(\mathrm{k})(1)(\mathrm{A})$ limited federal courts' exercise of personal jurisdiction to what state courts could exercise when borrowing that state's statutory authority).

24 See, for example, Chandler $v$ Barclays Bank PLC, 898 F2d 1148, 1154 (6th Cir 1990) (stating national contacts theory applies when statutory authority comes from a federal statutory national service provision).

25 See 15 USC $\$ 22$ (providing for worldwide service of process for certain corporate antitrust defendants).

26 See Foster-Miller, Inc v Babcock \& Wilcox Canada, 46 F3d 138, 145 (1st Cir 1995) ("It is apodictic that the plaintiff, who bears the burden of proving the existence of in personam jurisdiction, must carry the devoir of persuasion on the elements of relatedness and minimum contacts.") (citations omitted); Charles Alan Wright and Arthur R. Miller, 5A Federal Practice and Procedure: Civil $2 d \S 1351$ at 226 (West 2d ed 1990 \& Supp 2001) ("The most common formulation is that the plaintiff bears the ultimate burden of demonstrating that personal jurisdiction over the defendant exists by a preponderance of the evidence.").

27 See McCormick on Evidence $\S 337$ (cited in note 11) (discussing the burden of pleading).

28 Id $\S 336$ at 508 ("The burden of producing evidence on an issue means the liability to an adverse ruling .... if evidence on the issue has not been produced.").

29 See id ("The jury must be told that if the party having the burden of persuasion has failed to satisfy that burden, the issue is to be decided against that party. If there is no jury and the judge is in doubt, the issue must be decided against the party having the burden of persuasion.").

30 See notes 26-29. 
any single state created a gap in jurisdiction." This gap prevented the enforcement against such a defendant of most federal laws, since the majority of federal laws failed to provide for nationwide service of process. ${ }^{32}$ Omni Capital International, Ltd $v$ Rudolf Wolff \& Co, Ltd called attention to this jurisdictional gap. In Omni Capital, an action arising under a federal act, ${ }^{34}$ the impleaded defendant did not have sufficient contacts with the forum state, yet did have potentially adequate contacts with the nation as a whole. ${ }^{35}$ The Supreme Court dismissed the claim against the impleaded defendant. ${ }^{36}$ The Court, however, called for the drafting of a rule that would expand the jurisdictional reach of federal courts to fill this gap. ${ }^{37}$ Rule $4(k)(2)$ was added in $1993^{33}$ in response to this suggestion. ${ }^{39}$

The purpose of the new rule was to extend "the reach of federal courts to impose jurisdiction over the person of all [foreign] defendants against whom federal law claims are made and who can be constitutionally subjected to [ ] jurisdiction." ${ }^{40}$ Rule $4(\mathrm{k})(2)$ "enables district courts to exercise jurisdiction, if permissible under the Constitution and not precluded by statute, when a federal claim is made against a defendant not subject to the jurisdiction of any single state.", The new rule provides statutory authority under a specific circumstance (that is, a case involving a federal question and a defendant not subject to jurisdiction in another state) for a federal court to exercise its full constitutional power by examining the defendant's contacts with the nation as a whole.

31 See notes 13-16 and accompanying text (discussing the history of federal personal jurisdiction prior to the adoption of Rule $4(\mathrm{k})(2))$.

32 See note 25 and accompanying text.

33484 US 97 (1987) (holding that the court could not make a rule allowing for service where neither a federal statute nor the Federal Rules of Civil Procedure allowed for service on the defendants).

34 Id at 99-100 (arising under the Commodities Exchange Act).

35 Id at $101-02$.

36 Id at 111.

37 Id ("A narrowly tailored service of process provision, authorizing service on an alien in a federal-question case when the alien is not amenable to service under the applicable state longarm statute, might well serve the ends of the [Commodities Exchange Act] and other federal statutes.").

38 FRCP 4(k), Advisory Committee's Note (1993) ("Paragraph (2) [of Rule 4(k)] is new.").

39 The Advisory Committee stated:

This paragraph [4(k)(2)] corrects a gap in the enforcement of federal law... [T]he defendant was shielded from the enforcement of federal law by the fortuity of a favorable limitation on the power of state courts, which was incorporated into the federal practice by the former rule. In this respect, the revision [adding Rule $4(\mathrm{k})(2)$ ] responds to the suggestion of the Supreme Court made in [Omni Capital, 484 US at 111].

FRCP 4(k), Advisory Committee's Note (1993).

40 Id.

41 Id.

42 See notes 17-25 and accompanying text (discussing the interrelationship between statu- 
D. Application of Rule 4(k)(2)

Rule 4(k)(2) provides:

If the exercise of jurisdiction is consistent with the Constitution and laws of the United States, serving a summons or filing a waiver of service is also effective, with respect to claims arising under federal law, to establish personal jurisdiction over the person of any defendant who is not subject to the jurisdiction of the courts of general jurisdiction of any state. ${ }^{43}$

Courts have interpreted this language to mandate three requirements. First, the plaintiff's claim must arise under federal law. Second, the exercise of jurisdiction must comport with the constitutional requirement of the Fifth Amendment's Due Process Clause ${ }^{45}$ and not offend any federal laws. ${ }^{46}$ These two requirements are standard jurisdictional elements, but the third element requires the proof of a negative - that the potential defendant is not subject to jurisdiction in any state court. ${ }^{47}$ Because each state's jurisdiction is limited by statute and the Due Process Clause, this negation element requires a statutory decision and a constitutional decision for each state.

\section{CURRENT LAW: PRESENT AlLOCATION OF THE BURDEN OF PROOF IN RULE 4(K)(2)}

While the plaintiff most often bears the jurisdictional burden, courts vary in allocating the burden under Rule 4(k)(2). Largely, this variation is due to the negation element. ${ }^{48}$ Under Rule 4(k)(2), courts either explicitly or implicitly allocate the burden of persuasion to the

tory and constitutional authority).

43 FRCP 4(k)(2).

44 United States v Swiss American Bank, Ltd, 191 F3d 30, 38 (1st Cir 1999) ("[T]he plaintiff's claim must be one arising under federal law.").

45 Id at 36 ("[T] he applicable constitutional requirements devolve from the Fifth rather than the Fourteenth Amendment."), citing, inter alia, FRCP 4(k), Advisory Committee's Note (1993). See also Wright and Miller, 4 Federal Practice and Procedure $\S 1068.1$ at 601 (cited in note 1), citing DeJames v Magnificence Carriers, Inc, 654 F2d 280 (3d Cir 1981) (Gibbons dissenting):

The Fifth Amendment requires only that the forum be a fair and reasonable place at which to compel the defendant's appearance .... and that he have notice and a reasonable opportunity to be heard. A defendant's national contacts enter into the Fifth Amendment fairness analysis, for it would be unreasonable to subject to suit in the United States a foreign national defendant who had but one fleeting connection with this country.

46 See Swiss American Bank, $191 \mathrm{~F} 3 \mathrm{~d}$ at 38 ("[T] he federal courts' exercise of personal jurisdiction over the defendant must not offend the Constitution or other federal law.").

47 Id at 38 (" $\mathrm{T}]$ he putative defendant must be beyond the jurisdictional reach of any state court of general jurisdiction.").

48 The negation element requires that the defendant "is not subject to the jurisdiction of the courts of general jurisdiction of any state." FRCP $4(k)(2)$. 
plaintiff. ${ }^{49}$ Courts differ, however, as to how to treat the burden of production. Most courts have followed the traditional allocation of placing the burden of production on the plaintiff to prove all the elements of Rule 4(k)(2) jurisdiction. ${ }^{50}$ However, the Seventh Circuit has shifted the burden of production entirely to the defendant, ${ }^{\text {s. }}$ while the First Circuit has formulated a burden-shifting approach in an attempt to reach the most equitable result. ${ }^{22}$ Part II.A provides an example of a court allocating the burden of production to the plaintiff. Part II.B examines the Seventh Circuit's allocation to the defendant. Part II.C discusses the First Circuit's burden-shifting approach.

\section{A. Plaintiff's Burden of Production}

The majority of courts that have applied Rule 4(k)(2) jurisdiction have allocated the burden of production, either explicitly or implicitly, to the plaintiff. ${ }^{s 3}$ In United States $v$ Offshore Marine Ltd $^{\text {s4 }}$, the court addressed the plaintiff's claim that the burden should be on the defendant, "answer[ing] resoundingly in the negative.", Finding no lan-

49 See, for example, United States $v$ Swiss American Bank, Ltd, 191 F3d 30, 42 (1st Cir 1999) ("The plaintiff at all times retains the devoir of persuasion on the ultimate issue."), citing St. Mary's Honor Center v Hicks, 509 US 502, 507 (1993).

50 See, for example, Smith v S\&S Dundalk Engineering Works, Ltd, 139 F Supp 2d 610, 622 (D NJ 2001) ("Under this Rule, it remains plaintiffs' burden to produce competent evidence of sufficient contacts with the United States to justify the district court's assertion of either specific or general jurisdiction."), citing, inter alia, BP Chemicals, Ltd v Formosa Chemical \& Fibre Corp, 229 F3d 254, 259 (3d Cir 2000).

51 See ISI International, Inc v Borden Ladner Gervais LLP, 256 F3d 548, 552 (7th Cir 2001) (finding the defendant failed to meet the burden to "knock out Rule $4(\mathrm{k})(2)$ ").

52 See Swiss American Bank, 191 F3d at 41-42 ("If the plaintiff makes out his prima facie case, the burden shifts to the defendant.").

53 See, for example, BP Chemicals Ltd v Formosa Chemical \& Fibre Corp, 229 F3d 254, 258-59 (3d Cir 2000) (stating that in a Rule $4(\mathrm{k})(2)$ inquiry the burden of production remains with the plaintiff); Smith $v S \& S$ Dundalk Engineering Works, 139 F Supp 2d 610, 621-22 (D NJ 2001) (providing that the burden to show the three elements of Rule 4(k)(2) jurisdiction rests on the plaintiff); Eggear $v$ Shibusawa Warehouse Co, 2001 US Dist LEXIS 2868, *13 (E D Pa) ("Plaintiffs, not [defendant], bear the burden of proving jurisdiction under Rule 4(k)(2)."); In re Vitamins Antitrust Litigation, 120 F Supp 2d 58, 72 (D DC 2000) (dismissing claim for plaintiff's failure to show defendant is not subject to jurisdiction in any state); $R$. Griggs Group Lid v Consolidated Shoe, Inc, 1999 US Dist LEXIS 5426, *6-7 (N D Cal) (finding plaintiff failed to meet his burden of establishing jurisdiction under Rule 4(k)(2)); United States v Offshore Marine Ltd, 179 FRD 156, 160 (D Virgin Islands 1998) ("[T]o survive a motion to dismiss for want of personal jurisdiction, the plaintiff bears the burden."); CFMT, Inc v Steag Microtech, Inc, 1997 US Dist LEXIS $7905, * 23$ (D Del) ("Plaintiffs are also required to demonstrate that [defendant] is 'not subject to the jurisdiction of the courts of general jurisdiction of any state."'), quoting Rule 4(k)(2); Dorian v Harich Tahoe Development, 1995 US Dist LEXIS 21749, *13 (N D Cal) ("[P]laintiffs have not satisfied the other requirements for Rule 4(k)(2) jurisdiction.").

54179 FRD 156 (D Virgin Islands 1998). Offshore Marine is used as the case example because it contains the most detailed discussion of the burden allocation (even though its discussion is limited and conclusory). Other courts simply assume the burden is on the plaintiff. See note 53 (collecting cases).

55 Offshore Marine, $179 \mathrm{FRD}$ at 159. 
guage addressing the allocation of the burden in the text of the rule, the court looked to the traditional allocation of the burden. ${ }^{56}$ It did not discuss the policy or practical problems, instead relying on cases standing for the proposition that the burden in personal jurisdiction motions falls on the plaintiff."

\section{B. Defendant's Burden of Production}

In ISI International, Inc v Borden Ladner Gervais $L L P{ }^{s 8}$ the Seventh Circuit implicitly allocated the burden to the defendant. ${ }^{59}$ The plaintiff did not raise Rule 4(k)(2) jurisdiction and neither party briefed the matter, but the court raised the issue on its own during oral argument. ${ }^{(\mathrm{s})}$ After pointing out the multiple constitutional decisions that would be necessary if the burden were on the plaintiff, the court found it sensible to place some of the burden on the defendant. ${ }^{6 .}$ As the court raised Rule $4(\mathrm{k})(2)$ as the ground for personal jurisdiction during oral arguments, ${ }^{62}$ the plaintiff was apparently not required to meet any initial burden.

56 Id at 160 ("The question which party bears the burden of proving ... that the defendant is not subject to jurisdiction in any state appears to be an issue of first impression in this Court and in this Circuit, probably because it is generally the plaintiff's duty to allege and prove personal jurisdiction.").

57 Id ("Accordingly, to survive a motion to dismiss for want of personal jurisdiction, the plaintiff bears the burden to prove that [defendant] is not otherwise subject to service of process in any state, as well as every other element of the federal long-arm rule embodied in Fed. R. Civ. P. 4(k)(2).").

58256 F3d 548 (7th Cir 2001).

59 Id at 552. Additionally, in Central States, Southeast and Southwest Areas Pension Fund v Reimer Express World Corp, 230 F3d 934 (7th Cir 2000), the Seventh Circuit placed some burden on the defendant to show that jurisdiction is proper in another state in order to defeat Rule $4(k)(2)$ jurisdiction. Id at 940 . While failing to fully address burden allocation, the Court appears to shift at least some of the burden to the defendant but does not explain its reasoning for doing so or show the limits of the shift. See id. See also notes 64-74 and accompanying text for a discussion of burden-shifting allocation.

60 See ISI International, 256 F3d at 551-52 ("[Plaintiff] did not rely on Rule 4(k)(2), but [defendant's] appellate lawyer was ready for the questions asked during the oral argument."). See also Aerogroup International, Inc v Marlboro Footworks, Ltd, 956 F Supp 427, 438-42 (S D NY 1996) (undertaking, sua sponte, a Rule 4(k)(2) analysis of the defendant's amenability to jurisdiction in California (as the only other possible state)).

61 ISI International, 256 F3d at 552. Discussing the possibility that Rule $4(\mathrm{k})(2)$ requires 51 constitutional decisions, the court stated that it "must first determine that the United States has power and then ensure that none of the 50 states does so. The constitutional analysis at the federal level is unavoidable but usually simple.... Constitutional analysis for each of the 50 states is eminently avoidable by allocating burdens sensibly." Id.

62 Id ("[Plaintiff] did not rely on Rule 4(k)(2), but [defendant's] appellate lawyer was ready for the questions asked during the oral argument.").

63 See id ("[Defendant] had it within its power to knock out Rule $4(\mathrm{k})(2)$ by agreeing that it is subject to personal jurisdiction in some other state. It proved unwilling to do so. We therefore conclude that under Rule $4(\mathrm{k})(2)$ jurisdiction is proper."). 


\section{Shifting the Burden of Production}

In United States $v$ Swiss American Bank, $L t d{ }^{64}$ the First Circuit advocated a burden-shifting approach. ${ }^{65}$ The court found it permissible to tailor rules to reach the most equitable result ${ }^{66}$ and analogized from the burden-shifting arrangements used in employment discrimination cases. ${ }^{67}$ The court held that the plaintiff must make a prima facie showing that the claim arises under federal law, that jurisdiction is not available under any situation-specific federal statute, and that the defendant's contacts with the United States are sufficient to satisfy the constitutional requirements. ${ }^{69}$ Additionally, the plaintiff must certify that, based on information readily available to him, the defendant cannot be sued in another state. ${ }^{69}$ Once the plaintiff establishes this prima facie showing, the burden shifts to the defendant. ${ }^{70}$ The defendant may either argue that its contacts are insufficient to comport with constitutional requirements or that it is subject to suit in another state."

If the defendant challenges the plaintiff's prima facie showing of constitutionality or a claim under federal law, the burden returns to the plaintiff to establish those claims. ${ }^{2}$ If the defendant contests on the grounds that it is subject to the jurisdiction of another state, the plaintiff may then either transfer, discontinue its action, or contest the defendant's claim. ${ }^{3}$ Based on this allocation, the First Circuit concluded

64191 F3d 30 (1st Cir 1999).

65 Swiss American Bank, 191 F3d at 41-42. See also Estates of Yaron Ungar and Efrat Ungar $v$ Palestinian Authority, 153 F Supp 2d 76, 92-93 (D RI 2001) (following Swiss American Bank); In re Vitamins Antitrust Litigation, 120 F Supp 2d 45, 57 (D DC 2000) ("Under Fed. R. Civ. P. $4(k)(2)$, this burden shifts to defendants only after plaintiffs have certified that, to the best of their knowledge, these defendants are not subject to jurisdiction in any state in the United States."). Consider Stephen B. Burbank, The United States' Approach to International Civil Litigation: Recent Developments in Forum Selection, 19 U Pa J Intl Econ L 1, 13 (1998) (suggesting a broad outline for a similar burden-shifting regime vis-à-vis the Rule $4(k)(2)$ negation requirement).

66 Swiss American Bank, 191 F3d at 41, citing McDonnell Douglas Corp $v$ Green, 411 US $792,802-05$ (1973) (tailoring the burden allocation rule in the employment discrimination context).

67 Swiss American Bank, 191 F3d at 41, citing St. Mary's Honor Center v Hicks, 509 US 502, 506-07 (1993) (applying a burden-shifting approach that requires the plaintiff to make a prima facie case of racial discrimination and then shifts the burden of production to the defendant to show the specified acts were done for legitimate business purposes). St. Mary's also cites, for the same proposition, Texas Department of Community Affairs $v$ Burdine, 450 US 248, 252-56 (1981), and McDonnell Douglas, 411 US at 802-05.

68 Swiss American Bank, 191 F3d at 41.

69 Id.

70 Id.

71 Id.

72 Id at 42.

73 Id. 
that the burden-shifting method best balances the competing concerns, particularly because only the burden of production is shifted.

\section{NoRMATIVE AlLOCATION OF THE BURDEN OF PRODUCTION UNDER RULE 4(K)(2)}

Against this background, this Comment considers how the burden of production should be allocated under Rule 4(k)(2). Part III.A discusses the economics of burden allocation by examining Bruce Hay's model for general burden allocation" and then applies that model to Rule 4(k)(2). Part III.B dismisses unitary allocation to either the plaintiff or the defendant. Part IV then concludes that Swiss Bank's burden-shifting approach best minimizes costs.

\section{A. Economics of Burden of Production Allocation}

1. Economics of burden allocation in general.

Courts should allocate the burden of proof so as to minimize the social costs associated with deciding disputes, ${ }^{76}$ unless another important concern justifies the toleration of some economic inefficiency. Burden allocation affects two social costs of dispute resolution: process and error costs." Process costs include the resources spent by each party attempting to achieve the desired result. ${ }^{73}$ Error costs are the harmful results flowing from a decision opposite from the one that the evidence supports. ${ }^{79}$ Error costs fall into two categories: false positives (the defendant is subject to suit wrongly) and false negatives (the defendant is not subject to suit wrongly). The process and error costs are affected at three stages of the litigation process: filing (plaintiff decides to file suit); negotiation (parties bargain over potential settlement); and litigation (parties invest resources to gather and present

74 See id ("We think that this schematic fairly balances the equities and comports with congressional intent, particularly since we envision the defendant's burden as a burden of production only."). See also notes 119-24 and accompanying text (discussing the disadvantage of shifting the burden of persuasion).

75 See Bruce L. Hay, Allocating the Burden of Proof, 72 Ind L J 651, 651 (1997). The model described in Part III.A comes from Hay's article with some modification. See also Richard A. Posner, An Economic Approach to the Law of Evidence, 51 Stan L Rev 1477, 1502 n 55 (1999) (citing Hay).

76 See Hay, 72 Ind $\mathrm{L} J$ at 651 (cited in note 75) (stating that the goal of allocating the burden of proof from a law and economics perspective is to minimize social costs); Thomas R. Lee, Pleading and Proof: The Economics of Legal Burdens, 1997 BYU L Rev 1, 4 ("The basic theory of cost minimization may also be used to develop an economic model for evaluating the law's assignments of burdens."); Posner, 51 Stan L Rev at 1502-04 (cited in note 75) (discussing burden allocation with cost minimization as the goal).

77 Hay, 72 Ind L J at 654 (cited in note 75).

78 Id.

79 Id.

80 See Posner, 51 Stan L Rev at 1504 (cited in note 75). 
evidence). ${ }^{81}$ Cost minimization requires evaluating the process and error costs at each stage of the litigation. Given this model, courts should allocate the burden of proof to minimize the combined process and error costs based on the parties' decisions given different burden allocations.

Economic analysis supports the traditional allocation of the burden to the plaintiff and this allocation should be the dominant rule. However, four factors may justify deviation from this rule in specific dispute circumstances: (1) the ex ante probability of the plaintiff's claim being meritorious is high; (2) the cost to the plaintiff of presenting evidence is higher than the cost to the defendant; (3) the amount at stake is high; or (4) the social costs of a false positive (error in the plaintiff's favor) is less than the cost of a false negative (error in the defendant's favor). ${ }^{84}$ Any of these four factors indicate that allocation to the plaintiff could result in higher total costs, potentially warranting a shift of the burden to the defendant.

First, if there is a high probability that the plaintiff's claim is meritorious, allocation to the defendant increases the probability of default

81 Hay, 72 Ind L J at 655 (cited in note 75).

82 Cost minimization means taking account of parties' likely action in each stage of litigation in order to assess the overall cost. Id at 655 . For example, any increase in cost to the plaintiff will result in fewer filings, as the expected outcome will be greater than the expected cost in fewer cases. Id at 658.

Equilibrium is reached where the value of the outcome, $B$, multiplied by the probability the evidence will affect the outcome, $p$, equals the cost of finding and presenting the evidence, $C$ : that is, $C=(p)(B)$. Id at 661. See also Posner, 51 Stan L Rev at 1481 (cited in note 75) (discussing a similar equilibrium equation).

83 See Posner, 51 Stan L Rev at 1502-03 (cited in note 75) (internal citation omitted):

It makes sense, as a way of economizing on the time of the tribunal (as well as reducing nuisance litigation), to require the plaintiff, as a precondition to getting to trial, to submit evidence that if believed would be likely to carry the day with the jury, before the defendant is required to submit any evidence. This assumes that the cost to the plaintiff of obtaining this evidence is not disproportionately greater than the cost to the defendant of obtaining contrary evidence.

See also Hay, 72 Ind L J at 677 (cited in note 75) (suggesting that "as a general rule, the burden of proof on contested issues should go to the plaintiff"); Lee, 1997 BYU L Rev at 6 (cited in note 76) (listing "economic justifications for a default rule that assigns burdens to plaintiffs").

84 See Hay, 72 Ind L J at 673-77 (cited in note 75) (describing factors which may require a shift of the default allocation to the plaintiff in order to minimize costs); Lee, 1997 BYU L Rev at 16-28 (cited in note 76) (offering two justifications for deviation from the default assignment to the plaintiff: relative cost of proof and economization of error costs). See also Posner, 51 Stan L Rev at 1502-03 (cited in note 75) (stating that the allocation of the burden to the plaintiff makes sense as long as the cost to the plaintiff of presenting the evidence is not disproportionately higher than defendant's costs of presenting the evidence).

85 Examples of areas where the courts have placed the burden on the defendant include: res ipsa loquitur, Lee, 1997 BYU L Rev at 19-20 (cited in note 76); proving copying in copyright law, id; and negligence per se, Hay, 72 Ind $\mathrm{L} J$ at 678 (cited in note 75) (discussing res ipsa loquitur and negligence per se rules as exceptions to the dominant rule of allocating the burden to the defendant). 
by the defendant (or more likely settlement, because the case is meritorious), keeping process costs lower. ${ }^{86}$ In addition, error costs are higher if the burden is allocated to the plaintiff, because the chance of an erroneous decision increases if the burden rests with a party that is more likely correct. ${ }^{87}$ Second, if the relative cost to the plaintiff of presenting the evidence is higher, allocation to the defendant will reduce error costs, because the lower cost to the defendant increases the likelihood that the defendant (as compared to the plaintiff) will find it worthwhile to present evidence at all (that is, not default). ${ }^{8 s}$ Process costs, however, are inconclusive. If evidence is presented, then process costs are lower as the lowest cost provider produces the information. The probability of evidence being presented at all is higher because the defendant's lower costs means there are more cases in which presenting the evidence, and not defaulting or settling, is rational. ${ }^{89}$ Third, if the amount at stake is high, allocation to the plaintiff increases process costs, because the plaintiff would likely produce more evidence. Error costs are indeterminate: the increased production of evidence should reduce error rates, but the amount at stake will magnify each error. ${ }^{90}$ Fourth, if an error in the plaintiff's favor (a false positive) is more costly than an error in the defendant's favor (a false negative), process costs are not affected, but error costs increase. This is because the magnitude of each error increases (despite a lack of change in the likelihood of error). ${ }^{\text {" }}$

86 See Hay, 72 Ind L J at 671 (cited in note 75 ) ("[A]n increase in the probability that a party is correct has the effect of raising the cost of giving that party the burden of proof."). See also Lee, 1997 BYU L Rev at 27-28 (cited in note 76) (suggesting that while the probable merit of a case may economize on costs, this factor has no useful application in practice due to the difficulty, ex ante, of making a determination of the merits of the case).

87 See Hay, 72 Ind L J at 663 (cited in note 75).

88 See id at 664 (cited in note 75); Lee, 1997 BYU L Rev at 16-20 (cited in note 76) (discussing a "relative-cost-of-proof theory" to justify shifting the burden to defendants instead of the default allocation of burdens to plaintiffs).

89 See Hay, 72 Ind L J at 664 (cited in note 75).

90 See id. More information through greater production of evidence should help the decisionmaker reach the correct result. Of course, as the amount at stake rises the cost of any single error increases. These two effects will partially offset each other and it is difficult to determine which will dominate. See id.

91 See id at 664 (cited in note 75). It would be necessary to be able to make an ex ante judgment as to the relative magnitude of false positives to false negatives in order to use this factor in determining the proper burden allocation.

Defamation is an example of an area where courts feel confident in making such a judgment. The presumption that defamatory statements are presumed false (defendants have the burden of proving them true) reflects the common law's respect for reputations and implicit judgment that false negatives (errors in the defendant's favor) are of greater relative magnitude (that is, the error cost from a false negative is greater). See Lee, 1997 BYU L Rev at 22 (cited in note 76). 
2. Economics of Rule 4(k)(2) burden allocation.

To determine the optimal allocation of the burden of proof under 4(k)(2), this Comment applies the Hay model ${ }^{92}$ to Rule 4(k)(2) in an attempt to minimize social costs. Of the four factors warranting a shift from the traditional burden allocation to the plaintiff, two are relevant to determining burden allocation under Rule 4(k)(2): the probable merits of a claim and relative cost of presenting evidence. The other two factors are not implicated because they are indeterminable in the context of Rule 4(k)(2). First, the amount at stake cannot be isolated as a factor in jurisdictional cases because all cases involve personal jurisdiction. ${ }^{93}$ Second, the magnitude of false positives and negatives in Rule 4(k)(2) cases appears to be indistinguishable ex ante. ${ }^{4}$ Regardless, in light of the absence of clear evidence on the relative error costs, this Comment will assume that the error costs are roughly equivalent. ${ }^{\text {9s }}$

To determine the optimal allocation of the burden of production under Rule 4(k)(2), this Part uses an inequality to express the relationship between the two relevant variables. Courts should allocate the burden of proof to the plaintiff if the probability that jurisdiction is proper $\left(p_{\text {meni }}\right)$ multiplied by the cost to the plaintiff of presenting evidence $\left(C_{\Pi}\right)$ is less than the probability of jurisdiction not being proper $\left(p_{\text {meritess }}\right)$ multiplied by the cost of the defendant presenting the evidence $\left(C_{\Delta}\right)$.

92 See Part III.A.1.

93 One might argue that in cases involving foreign defendants and jurisdictional disputes, the plaintiff has a higher cost and so requires a higher amount in dispute to bring suit. This argument presupposes, however, that the plaintiff will bear the burden of proving that the court has jurisdiction. If the defendant bears the burden, the cost of bringing the suit will go down, as will the amount required to bring the suit. Thus, this Comment will treat the amount in controversy as unknown and not affecting the allocation decision.

94 See Posner, 51 Stan L Rev at 1504 (cited in note 75) ("In the typical civil trial, there is no basis for supposing that Type I errors (false positives ...) on average impose higher costs than Type II errors (false negatives ...)."). The error costs of a false positive include the inconvenience to a foreign defendant (including being subjected to American discovery), due process concerns, and the cost of cash transfers (or at least the increased probability of cash transfer). The error costs of a false negative include the inability of a plaintiff to redress a wrong, a reduction in proper incentives, or the inconvenience to a plaintiff of suing in a foreign nation.

95 Most civil trials involve only money, and as such the only error cost involves wealth transfers and, thus, is not significant. See Henry L. Chambers, Jr., Getting It Right: Uncertainty and Error in the New Disparate Treatment Paradigm, 60 Albany L Rev 1, 6 (1996) (arguing that because most civil trials only involve money, there is no reason for the legal system to favor false positives or false negatives).

96 Adapted from Bruce L. Hay and Kathryn E. Spier, Burdens of Proof in Civil Litigation: An Economic Perspective, $26 \mathrm{~J}$ Legal Stud 413, 418 (1997) (stating that the plaintiff should be allocated the burden where (probability that $X$ occurred) multiplied by (plaintiff's cost of showing $X$ occurred) < (probability that $X$ did not occur) multiplied by (defendant's costs of showing $X$ did not occur)). 


$$
\left(p_{\text {merit }}\right)\left(C_{\Pi}\right)<\left(p_{\text {meriless }}\right)\left(C_{\Delta}\right) \rightarrow \text { Plaintiff's Burden." }
$$

The plaintiff should have the burden if the probable merit of the case is low, assuming costs are equal. ${ }^{\text {s }}$ However, the defendant should have the burden if the relative cost of the plaintiff presenting the evidence is higher, assuming the probable merits are equal."

Thus, in allocating the Rule $4(\mathrm{k})(2)$ burden, the "probable merit of a claim" factor favors allocation to the plaintiff. The relative level of merit is indeterminable and depends on the allocation rule. Placing the burden on the plaintiff raises the probable merits because the burden raises the putative plaintiff's costs. This increased cost to the plaintiff reduces the incentive to bring a meritless suit in hopes of extracting a settlement or achieving an erroneous decision in its favor. ${ }^{100}$ Thus the probable merit of the claim is greater when the burden is allocated to the plaintiff compared with when it is allocated to the defendant. This indicates that the plaintiff should bear the burden.

The "relative cost of presenting evidence" factor, however, favors allocation to the defendant ${ }^{101}$ (at least on the amenability of suit in another state). The defendant is the lowest cost provider of evidence because the defendant has greater access to the necessary jurisdictional information, and need not go through costly discovery and research to satisfy the burden. ${ }^{102}$ These two factors point to opposite allocations; thus, there is no clear preference for allocation to either party.

97 Similarly, the burden should be allocated to the defendant where the reverse is true: $\left(p_{\text {ment }}\right)\left(C_{\Pi}\right)>\left(p_{\text {mentess }}\right)\left(C_{\Delta}\right) \rightarrow$ Defendant's Burden.

98 Where $p_{\text {mont }}$ is low then $p_{\text {mentless }}$ is high because $p_{\text {ment }}$ plus $p_{\text {mertles }}$ must equal one. If costs are held constant, $\left(p_{\text {mentles }}\right)\left(C_{\Delta}\right)$ is higher than $\left(p_{\text {ment }}\right)\left(C_{\Pi}\right)$, which should result in allocation to the plaintiff.

99 In this situation, $C_{\Pi}$ is larger than $C_{\Delta}$. If the probable merits are held constant, $\left(p_{\text {men1 }}\right)\left(C_{n}\right)$ is greater than $\left(p_{\text {mentcess }}\right)\left(C_{\Delta}\right)$, which should result in allocation to the defendant.

100 The plaintiff will sue when the probability of winning, $p$, multiplied by the value of the outcome, $B$, is greater than the plaintiff's direct costs, $C$ : that is, $(p)(B)>C$. See Lee, 1997 BYU L Rev at 21 n 58 (cited in note 76). Requiring the plaintiff to bear some burden increases the plaintiff's costs. This makes it less likely that the inequality is met, as compared with complete allocation to the defendant. Id.

101 See id at 17 (arguing that allocation to the defendant based on relative cost of producing evidence "economizes on direct costs by providing incentives to the 'least-cost producer' of proof to produce the central 'core' of evidence to be shared by both parties").

102 The defendant has the evidence and does not have to undertake discovery to learn of its own actions. See Swiss American Bank, 191 F3d at 40 (noting that "the defendant typically controls much of the information needed to determine the existence and/or magnitude of its contacts with any given jurisdiction"); Posner, 51 Stan L Rev at 1503 (cited in note 75) (pointing out the inefficiencies that would follow if the plaintiff had the burden of proving the absence of affirmative defenses, because the plaintiff would have to anticipate a large number of potential defenses, effectively doing the defendant's legal research for it). 


\section{B. Unitary Burden Allocation: A Second Best Approach}

Allocation of the burden solely to the plaintiff or defendant offers advantages, but either unitary allocation is ultimately a secondbest option. Allocating the burden to the plaintiff has the advantage of increasing the likely merit of a suit. ${ }^{1.3}$ Allocation to the plaintiff has the disadvantages of placing the burden of producing evidence on the party that is the higher cost provider ${ }^{104}$ and making a court perform a negation decision that the defendant is not subject to the jurisdiction of each state. ${ }^{105}$ Allocating the burden to the defendant has the advantage of placing the burden on the lowest cost provider of evidence, ${ }^{106}$ but the disadvantage of reducing plaintiffs' costs, which results in increased filing of marginal cases. ${ }^{107} \mathrm{~A}$ case-by-case comparative analysis would be necessary to determine the relative advantage of each allocation if unitary allocation (allocation solely to one party) were the only option. However, as illustrated in Swiss Bank, a court may divide the burden and thereby more effectively allocate the burden.

\section{BURDEN-SHIFTING: OPTIMAL ALLOCATION OF THE BURDEN OF PRODUCTION UNDER RULE 4(K)(2)}

A burden-shifting approach minimizes the costs of dispute resolution under Rule 4(k)(2): placing the initial burden on the plaintiff reduces meritless suits; while placing on the defendant, the lower cost provider of information, the more costly burden of showing whether the defendant is subject to suit in another state. ${ }^{108}$ Part IV.A explains burden-shifting, and Part IV.B shows why an affirmative defense approach is a less attractive alternative than burden-shifting. Part IV.C refutes other potential objections.

\section{A. Burden-Shifting Approach}

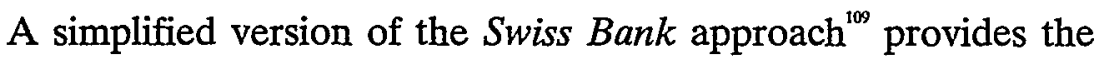
best solution to the burden allocation problem raised by Rule 4(k)(2). Under the burden-shifting standard, the plaintiff must produce a prima facie case as to the first two elements of Rule 4(k)(2) jurisdic-

103 See note 100 and accompanying text.

104 See Swiss American Bank, 191 F3d at 40 ("This paradigm in effect requires a plaintiff to prove a negative fifty times over - an epistemological quandary which is compounded by the fact that the defendant typically controls much of the information needed."). See note 102.

105 Each state would require independent statutory and constitutional decisions.

106 See notes 101-03 and accompanying text.

107 As the plaintiff's costs decrease, more putative suits will have an expected outcome greater than the expected cost. See note 100.

108 The burden-shifting approach shifts the burden of the negation element to the defendant following the plaintiff's prima facie case. See notes 109-19.

109 See notes 64-74 and accompanying text. 
tion: (1) a federal question in the claim; and (2) the constitutionality of jurisdiction (including minimum contacts and reasonableness). ${ }^{10}$

Once the plaintiff meets this initial burden, the defendant may challenge either prima facie claim. Additionally, the defendant may challenge the third element of Rule $4(\mathrm{k})(2)$ jurisdiction (not subject to the jurisdiction of another state) by showing a state in which it would be subject to suit. This showing of amenability to suit in another state would disprove the negation element." If the defendant does not argue that it is subject to the jurisdiction of another state, the plaintiff receives the benefit of not having to prove the defendant's nonamenability to suit in each and every state. If the defendant contests the federal question or constitutional elements, then the plaintiff maintains the burden of production and persuasion on these elements, the same as in traditional Rule 4(k)(1) jurisdiction. If the defendant chooses to argue that it is subject to suit in a state court, then the defendant bears the burden of production on its amenability to suit in another state. Regardless, the burden of persuasion remains with the plaintiff. $^{112}$

The plaintiff's burden of establishing a prima facie case under the burden-shifting approach reduces meritless claims. ${ }^{13}$ Burden-shifting also avoids relatively costly discovery ${ }^{114}$ and the multiple negation inquiries required for the plaintiff to prove the defendant is not subject to jurisdiction of any state. This approach increases the probability that a suit is meritorious, ${ }^{115}$ while forcing the lowest cost provider of the information to meet the most costly burden of production. ${ }^{116}$

110 See Swiss American Bank, 191 F3d at 41.

111 The defendant may argue in the alternative here, although such an argument places the defendant in a difficult situation. The defendant must argue that it is subject to suit in State $X$, while at the same time arguing that it does not have sufficient nationwide contacts. Rule $4(k)(2)$ was enacted, however, to expand the jurisdictional reach of federal courts, which inherently places a defendant in a more difficult situation. Additionally, the defendant has the choice and may choose not to argue in the alternative.

The First Circuit acknowledges the difficult place in which this catch-22 puts defendants, but recognizes that this interpretation best serves the purpose of Rule 4(k)(2). See Swiss American Bank, $191 \mathrm{F3d}$ at 41. More importantly, the defendant will narrow the number of negation decisions a court has to make, thereby reducing the court's cost.

112 See Swiss American Bank, 191 F3d at 42 ("The defendant's burden [is] a burden of production only.").

113 See notes 98-100 and accompanying text.

114 The burden is efficiently allocated to the lowest cost provider.

115 Meritless suits are both discouraged from being filed and screened out early in the process.

116 This approach is similar to the burden-shifting approach in McDonnell Douglas Corp v Green, 411 US 792, 802-03 (1973). The burden-shifting approach in employment discrimination contexts minimizes social costs in that it forces parties to reveal their case prior to trial, and allocates the majority of the gathering and presenting of evidence to the lowest cost provider of that information. See Posner, 51 Stan L Rev at 1504 (cited in note 75) (arguing that the burdenshifting rule of McDonnell Douglas minimizes costs). 


\section{B. Affirmative Defense Approach: A Less Attractive Alternative}

Another alternative to the unitary burden allocation would be to make the "amenability to suit in another state" element of Rule $4(k)(2)$ an affirmative defense. Like burden shifting, this affirmative defense approach reduces the number of meritless suits by allocating two elements to the plaintiff while placing the burden of the costly negation element on the lowest-cost provider of information. This option would also simplify the adjudicatory process, as the use of affirmative defenses is well known to the courts. ${ }^{117}$ The logistics would be straightforward. The defendant would have the choice of raising as a defense its amenability to suit in another state, and if raised would bear the burden of production and persuasion on the defense. Except for this one element necessary under Rule $4(\mathrm{k})(2)$, the burden of proof would remain with the plaintiff.

Two problems beset this approach, ultimately making it less attractive than burden-shifting, although still more attractive than a unitary allocation. First, the language of Rule 4(k)(2) does not support treating the negation element as an affirmative defense. Rule 4(k)(2) makes no mention of an affirmative defense, in contrast to statutes which expressly create affirmative defenses. ${ }^{118}$ Second, an affirmative defense approach shifts the burdens of pleading and persuasion, ${ }^{119}$ which is inconsistent with Rule 4(k)(1) jurisdictional burdens. ${ }^{120}$

The burden-shifting and affirmative defense approaches achieve similar results. Both place an initial burden on the plaintiff, reducing meritless suits, while placing on the defendant, the lowest cost provider, the most costly burden of showing whether the defendant is subject to suit in another state. ${ }^{121}$ Both approaches are preferable to unitary allocation, but the affirmative defense approach's lack of a textual basis and its inconsistency with the rest of Rule 4 make burden-shifting a better solution.

117 See FRCP 8(c) (providing for a number of affirmative defenses).

118 Nothing in the language of Rule 4(k)(2) implies that an affirmative defense would be appropriate. Compare 8 USC $\$ 1324 a$ (a)(3) (1994) ("A person or entity that establishes that it has complied in good faith with the requirements of subsection (b) ... has established an affirmative defense that the person or entity has not violated paragraph (1)(A).").

119 See ISI International, $256 \mathrm{~F} 3 \mathrm{~d}$ at 552.

120 See notes 26-30 and accompanying text. Such anomalies raise putative parties' information costs.

121 The affirmative defense approach allocates the entire burden of proof for the negation element of Rule 4(k)(2) to the defendant by making it an affirmative defense. See Part IV.B. The burden-shifting approach shifts the burden of the negation element to the defendant following the plaintiff's prima facie case. See notes 109-19. 


\section{Concern for Foreign Defendants, Due Process, and Administrative Expenses: Surmountable Hurdles to Burden-Shifting}

Two criticisms of the burden-shifting solution revolve around the equity of shifting any portion of the burden to the defendant. First, there is significant concern about subjecting a foreign defendant to personal jurisdiction. The Advisory Notes to Rule 4(k)(2) quote the Supreme Court, directing that particular care should be shown in subjecting foreign defendants to jurisdiction. ${ }^{12}$ This indicates that the courts should be cautious to shift any burden to a putative foreign defendant. This caution should be weighed, however, in light of Rule $4(\mathrm{k})(2)$ 's purpose of subjecting foreign defendants to the jurisdiction of federal courts. ${ }^{123}$ Additionally, courts should concentrate on minimizing the costs of dispute resolution, and this goal highlights the need to shift part of the burden.

Second, there is the concern that burden-shifting implicates due process. Arguably, allocation of the burden entirely to the defendant would be problematic, ${ }^{124}$ and one may even think that a shift of part of the burden raises due process issues. The burden-shifting approach does not offend due process because the minimum contacts necessary for jurisdiction to comport with due process are still required. Moreover, the plaintiff bears the responsibility of alleging (prima facie) minimum contacts and retains the burden of establishing the defendant's nationwide contacts if the defendant challenges the plaintiff's prima facie case of constitutionality. Therefore, regardless of who bears the burden of showing that the defendant is amenable to suit in another state, the defendant cannot be subject to jurisdiction where minimum contacts are not established. As a result the burden-shifting approach to Rule $4(\mathrm{k})(2)$ does not violate due process.

122 While not an element of Rule 4(k)(2) jurisdiction, a court should take special concern in finding jurisdiction over a foreign defendant: "The district court should be especially scrupulous to protect aliens who reside in a foreign country from forum selection so onerous that injustice could result. '[G]reat care and reserve should be exercised when extending our notions of personal jurisdiction into the international field." FRCP 4(k), Advisory Committee's Note (1993), quoting Asahi Metal Industries v Superior Court of California, Solano County, 480 US 102, 115 (1987), quoting United States v First National City Bank, 379 US 378, 404 (1965) (Harlan dissenting).

123 See notes 31-42 and accompanying text (discussing Rule 4(k)(2)'s purpose).

124 See Insurance Corp of Ireland, Ltd v Compagnie des Bauxites de Guinee, 456 US 694, 705-06 (1982) (discussing the due process concerns raised by using a discovery sanction to impose personal jurisdiction on a defendant). See also Lonny J. Hoffman, Rethinking the Special Appearance Rule: Does Rule 120A Offend Process When "Alter Ego" is Asserted as the Jurisdictional Basis?, 46 Baylor L Rev 559, 576-77 (1994) (suggesting that a shift of the jurisdictional burden entirely to the defendant may offend due process). Hoffman argued, "[T]he constitutional guarantees of International Shoe and its progeny are rendered meaningless if the plaintiff does not have to satisfy an initial allegation burden." Id at 566 . 
Finally, a third objection centers on the administrative difficulty of a two-step process. Administrative costs in time and resources actually support the burden-shifting approach. The multiple negation inquiries (each with statutory and constitutional elements) would require much greater time and effort than the relatively straightforward burden-shifting approach. Additionally, the courts have used burdenshifting approaches in other areas, including employment discrimination claims, ${ }^{125}$ and should be able to apply such an approach with little administrative difficulty.

\section{CONCLUSION}

The negation element of Rule 4(k)(2) makes its application expensive and complicated. As a result of this negation element, courts have struggled with allocating the burden of production. This Comment suggests that basic economics can shed light on this allocation and help courts minimize the cost of dispute resolution. Ultimately, this Comment suggests that unitary allocation of the burden of production is inefficient and urges adoption of the Swiss Bank burdenshifting approach. This approach should assist courts and parties in resolving disputes in a cost effective manner.

125 See note 116 (discussing burden shifting in the employment discrimination context). 


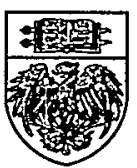

